THE SEXUAL CENTURY 
This page intentionally left blank 


\section{THE SEXUAL CENTURY}

ETHEL SPECTOR PERSON, M.D. 
Copyright $₫ 1999$ by Yale University.

All rights reserved.

This book may not be reproduced, in whole or in part, including illustrations, in any form (beyond that copying permitted by Sections 107 and 108 of the U.S. Copyright Law and except by reviewers for the public press), without written permission from the publishers.

Designed by Gregg Chase.

Set in Scala type by Keystone Typesetting, Inc., Orwigsburg, Pennsylvania.

Printed in the United States of America by Vail-Ballou Press, Binghamton, New York.

Person, Ethel Spector.

The sexual century / Ethel Spector Person.

p. $\mathrm{cm}$.

Includes bibliographical references and index.

ISBN 0-300-07604-5 (alk. paper)

I. Sex role. 2. Sex discrimination against women. 3. Sex rolePsychological aspects. 4. Sex differences (Psychology) 5. Gender identity. I. Title.

HQ1075.P46 1999

305.3-dc2I

$99-3459^{8}$

CIP

A catalogue record for this book is available from the British Library.

The paper in this book meets the guidelines for permanence and durability of the Committee on Production Guidelines for Book Longevity of the Council on Library Resources.

I0 $\quad \begin{array}{lllllllll}9 & 8 & 7 & 6 & 5 & 4 & 3 & 2 & \text { I }\end{array}$ 
IN MEMORY OF LIONEL OVESEY

An intuitive and brilliant analyst, inspired and inspirational teacher, original and rigorous thinker, researcher in psychoanalysis before such research was fashionable, he was, to me, a friend, mentor, and collaborator in those days when men were said not to mentor women. 
This page intentionally left blank 